DOI: 10.17707/AgricultForest.62.4.22

\author{
Ganna RUGUZOVA, Olga POKHYLCHENKO, \\ Irina IVANOVA, Yurii YAREMCHUK ${ }^{1}$
}

\title{
SOME FEATURES OF Pinus pumila (Pall.) Reg. AND Pinus armandii Franch. SEED FORMATION IN THE CONDITIONS OF INTRODUCTION
}

\begin{abstract}
SUMMARY
Female cone structure in two species - Pinus pumila (Pall.) Reg. and Pinus armandii Franch. in the conditions of introduction are presented in this paper. It has been demonstrated that number of scales and fertile/sterile scales index are similar to those in their native areas. At the beginning of the second year development (February) female gametophytes in both species were at freenuclear stage and only in some $P$. armandii ovules alveolar stage was noticed. It was found out that the main reason for ovules abortion is lack of pollination. However, ovules`abortion was also noticed at the second year and its reasons need to be studied in details.
\end{abstract}

Keywords: Pinus pumila, Pinus armandii, female cones, fertile scales, ovules, seeds

\section{INTRODUCTION}

Pinus L. genus is the largest in the family Pinaceae and includes more than 100 species. They are the most common coniferous tree worldwide and native to all continents and some oceanic islands of the northern hemisphere, chiefly in boreal, temperate, or mountainous tropical regions. In their native areas some species form large forests and used as timber source. From the other hand pines is a very important part of the world ecology. Pinus species are introduced all over the world as ornamental and timber trees. In this sphere nut producing pines are of the greatest interest as they are not only good ornamentals but could also provide highly nutritious nuts and some other products.

Growing plants outside their natural range needs some special studies for understanding their adaptive potential and reaction to the new growth conditions. One of the important parameters for evaluation of species' adaptability to the new growing conditions is their reproductive success. But it should be considered that reproductive cycle of most coniferous, and also in some Pinus species, is prolonged in time and influenced by number of factors.

\footnotetext{
${ }^{1}$ Ganna Ruguzova, Olga Pokhylchenko, National Botanical Garden named after N.N. Grishko NAS, 1 Timiryazev Street, Kyiv 01014, UKRAINE, Irina Ivanova The O.V. Fomin Botanical Garden of the Taras Shevchenko Kyiv National University,1 Simona Petlyury Street, Kyiv 01032, UKRAINE, Yurii Yaremchuk Dendropark "Vysokogirny", Bystrytsa village, Ivano-Frankivsk region 78436, UKRAINE

Notes: The authors declare that they have no conflicts of interest. Authorship Form signed online.
} 
Pinus pumila (Pall.) Reg. and Pinus armandii Franch. belong to the group commonly known as "white pines" or "soft pines" and are native to the East Asia. Three variations of $P$. armandii have been recognized within its native area (Wang and Hong, 2004) and some of them have the status of "endanged" taxons. Number of reports describes their genetics and relationships and only some works have studied reproductive cycle in this pine species (Zhang et al., 1992, Wang et al. 2007). There are some reports about reproductive cycle of $P$. pumila in its native area connected with the problem of interspecific hybridization between P. pumila and Pinus sibirica Du Tour. (Goroshkevich et al., 2008, Vasilyeva, Goroshkevich, 2013). Our investigations were aimed to the understanding the reasons of poor seed production in two introduced pine species - P. armandii and P. pumila.

\section{MATERIAL AND METHODS}

Pinus pumila (Pall.) Reg.

In its native areas is shrub or small tree $2-8 \mathrm{~m}$ tall, usually multistemmed with creeping branches and gray-brown bark. Needles 5 per bundle, trapeziform in cross section. Seed cones are erect, maturing to pale purple or redbrown, conical-ovoid or ovoid, 3-4.5 $\times 2.5-3 \mathrm{~cm}$, indehiscent or imperfectly dehiscent at maturity. Seed scales broadly subrhombic or rhombic-obovate. Mature seeds are dark brown, triangular-obovoid; 7-10 $\times$ 5-7 mm, wingless, abaxial margin is ridged.

It is distributed in Japan, North Korea, North Mongolia, Eastern Siberia from Yenisey River, some mountain regions of China (at 1000-2300 m elevation) - Heilongjiang, Jilin, Nei Mongol (Flora of China, 2016).

\section{Climatic conditions of its native growth regions.}

Winters are long with an average of -31 to $-15{ }^{\circ} \mathrm{C}$ in January, and summers are short and warm to very warm with an average of 18 to $23{ }^{\circ} \mathrm{C}$ in July. The annual average rainfall is 400 to 700 millimetres, concentrated heavily in summer.

We studied Pinus pumila plants grown in the O.V.Fomin Botanical Garden (Kyiv) and in the dendropark "Vysokogirny" (Highland) (Gorgany mountain range).

There are three plants of Pinus pumila are in the O.V.Fomin Botanical Garden (Kyiv). Two of them were planted in 1985 and the third - in 1982. Each tree has 5-7 trunks, diameter $2-10 \mathrm{~cm}$. The height is $2.5-3 \mathrm{~m}$. The start of vegetation varies from $8^{\text {th }}$ to $15^{\text {th }}$ April in different years. Male and female cones annually form on the plants 1985 year planted. In 2013 these trees produced 82 and 86 female cones per tree. Viability of pollen was $71-88 \%$ in the different years.

In the dendropark "Vysokogirny" Pinus pumila plants were brought from different natural habitats and planted in 1970. The start of vegetation was noticed at the end of May. Male and female cones formed annually. 


\section{Pinus armandii Franch.}

In its native areas is trees to $35 \mathrm{~m}$ tall with gray bark fissured into square plates or shed. Crown is conical or cylindric-pyramidal; branchlets are green, gray-green or brown, glaucous. Needles are 5(-7) per bundle, triangular in cross section. Pollen cones are erect or drooping, slender or stout, cylindric or ovoidellipsoid. Seed cones pedunculate (peduncle 2-3 cm), green, maturing yellow or brown-yellow, conical-cylindric, dehiscent at maturity, shedding seeds. Seed scales are rhombic-obovate. Seeds are yellow-brown, dark brown, or black, obovoid, 1-1.5 $\mathrm{cm} \times 6-10 \mathrm{~mm}$, wingless or abaxial margin ridged, rarely shortly winged.

It is distributed in China - South Gansu, Central and North-West Guizhou, Hainan, South-West Henan, West Hubei, South Shaanxi, South Shanxi, Sichuan, South-East Xizang, Yunnan at 900-3,500 m; North and Central Taiwan at altitudes of 2,300-3,000 m; North Myanmar.

\section{Climatic conditions of its native growth regions.}

Summers are warm to hot and winters are cold to very cold with so large diurnal temperature ranges that maxima often remain above $0^{\circ} \mathrm{C}$ even in winter. The average temperature is roughly 10 to $20^{\circ} \mathrm{C}$, with January temperatures ranging from 1 to $10^{\circ} \mathrm{C}$ and July temperatures ranging from 17 to $28^{\circ} \mathrm{C}$. The highest temperature can reach $41^{\circ} \mathrm{C}$, while the lowest temperature can drop to $14.9^{\circ} \mathrm{C}$. Total precipitation is between 500 and $1,000 \mathrm{~mm}$, falling mostly between May and October.

In the O.V.Fomin Botanical Garden Pinus armandii tree was planted in 1986. Its height is about $6 \mathrm{~m}$, trunk diameter $21 \mathrm{~cm}$. Male and female cons form annually. The start of vegetation was noticed from $9^{\text {th }}$ to $18^{\text {th }}$ April in different years. Pollen viability was $69-87 \%$.

\section{Climate of the introduction region.}

Kyiv has a humid continental climate with severe winters, no dry season, warm summers and strong seasonality (Köppen-Geiger classification: $\mathrm{Dfb})$. The warmest months are June, July, and August, with mean temperatures of 13.8 to $24.8^{\circ} \mathrm{C}$. The coldest are December, January, and February, with mean temperatures of -4.6 to $-1.1^{\circ} \mathrm{C}$. Snow cover usually lies from mid-November to the end of March, with the frost-free period lasting 180 days on average, but surpassing 200 days in recent years. Total annual precipitation averages $649 \mathrm{~mm}$.

"Vysokogirny" dendropark is located in the zone with minimum air temperature $-35.2^{\circ} \mathrm{C}$, maximum $+30.1{ }^{\circ} \mathrm{C}$ and mean year temperature $+4.5^{\circ} \mathrm{C}$. Total annual precipitation averages $1000 \mathrm{~mm}$.

\section{Embryological Methods}

$P$. armandii female cones pollinated in spring 2013 were collected in the plots of O.V. Fomin Botanic Garden in late March 2014 and P. pumila female 
cones - in the plots of O.V.Fomin Botanic Garden and in the dendropark "Vysokogirny" in late March 2014.

Bracts and ovules were separated and fixed in Karnua solution (96\% ethanol : chlorophorm : acetic acid, 6:3:1) and stored in 70\% ethanol. Materials for histological studies were dehydrated, infiltrated and embedded in paraffin (Pausheva, 1990). Sections 10-12 $\mu \mathrm{m}$ thick was obtained using the rotary microtome. They were mounted and stained by methyl-green and pyronin with alcian blue (Shevchenko et al., 1986; Sklonnaya, 1992). Analyses were carried out with light microscope Jenaval (Carl Zeiss), measurements and microphotograpes were made under the light microscop Axio Scope A.1 (Carl Zeiss) with analyses system Axio Cam ERc5s by the programme Axio Vision rel. 4.8.2.

\section{RESULTS AND DISCUSSION}

The period between pollination and seed maturity in $P$. pumila and $P$. armandii takes for about 1.5 year. In native growth regions pollination in $P$. armandii occurs in Aprile-May (Flora of China, 2016) and P. pumila (growing in the eastern part of West Siberia, $55^{\circ} 47^{\prime}$ с.ш., $109^{\circ} 33^{\prime}$ в.д.) it occurs in early June (Vasilyeva et al., 2010) while in Kyiv pollination in $P$. armandii occurs in 20-31 May and in P. pumila 8-20 May while in Gorgany mountains - in mid-June.After pollination both male and female gametophytes develop inside the ovules and it has been noticed for pine species (Pinus albicaulis Eng., Pinus contorta Doug. ) the early stage of female gametophyte development occur even in nonpollinated ovules (Owens, 2006, Owens et al. 2008). We studied female cones somewhere the middle between pollination and mature seeds. It should be noticed that $P$. pumila female cones collected in Kyiv and in Gorgany were almost at the same development stage. At that time $P$. armandii cones were $21 \times 11 \mathrm{~mm}$ (length $\mathrm{x}$ diameter) and consisted of the central axis and 60-67 tightly closed cone scales and $P$. pumila cones were $17 \times 8 \mathrm{~mm}$ (length $\mathrm{x}$ diameter) in Kiiv and $18 \times 10 \mathrm{~mm}$ in Gorgany and consisted of the central axis and 43-47 tightly closed cone scales (Table1). Our data for total scales number in P. pumila cones corresponds to those in native growth conditions (eastern part of West Siberia) as it has been recorded 42 \pm 6 ( $\min 30, \max 50$ ) per cone (Vasilieva and Goroshkevich, 2013).

Table 1. Pinus pumila and Pinus armandii cone analyses

\begin{tabular}{|c|c|c|c|c|c|c|c|c|}
\hline Species & $\begin{array}{c}\text { Cone } \\
\text { length } \\
(\mathrm{mm})\end{array}$ & $\begin{array}{c}\text { Cone } \\
\text { diameter } \\
(\mathrm{mm})\end{array}$ & $\begin{array}{c}\text { Total } \\
\text { scales }\end{array}$ & $\begin{array}{c}\text { Sterile } \\
\text { scales }^{*}\end{array}$ & Total & $\begin{array}{c}\text { two ovules } \\
\text { degenerate }\end{array}$ & $\begin{array}{c}\text { One ovule } \\
\text { degenerates }+ \\
\text { one develops }\end{array}$ & $\begin{array}{c}\text { Two } \\
\text { ovules } \\
\text { develop }\end{array}$ \\
\hline $\begin{array}{c}\text { Pinus pumila } \\
\text { (Kyiv) }\end{array}$ & $17.5 \pm 0.5$ & 8.0 & $44.5 \pm 1.5$ & $12.5 \pm 1.5$ & 32.0 & $5 \pm 1$ & $9.5 \pm 2.5$ & $8 \pm 2$ \\
\hline $\begin{array}{c}\text { Pinus pumila } \\
\text { (Gorgany) }\end{array}$ & $18 \pm 1$ & 10.0 & 47.0 & $16 \pm 1$ & $31 \pm 1$ & $3 \pm 1$ & $11 \pm 1$ & $8 \pm 1$ \\
\hline $\begin{array}{c}\text { Pinus } \\
\text { armandii }\end{array}$ & $21 \pm 0.33$ & $11 \pm 0.57$ & $62 \pm 2.33$ & $13 \pm 0.33$ & $49 \pm 1.85$ & $12 \pm 1.54$ & $15 \pm 4.25$ & $22 \pm 5.03$ \\
\hline
\end{tabular}

Note: data presented as mean \pm SEM

*- sterile scales include both scales without ovules and scales with rudimentary ovules 


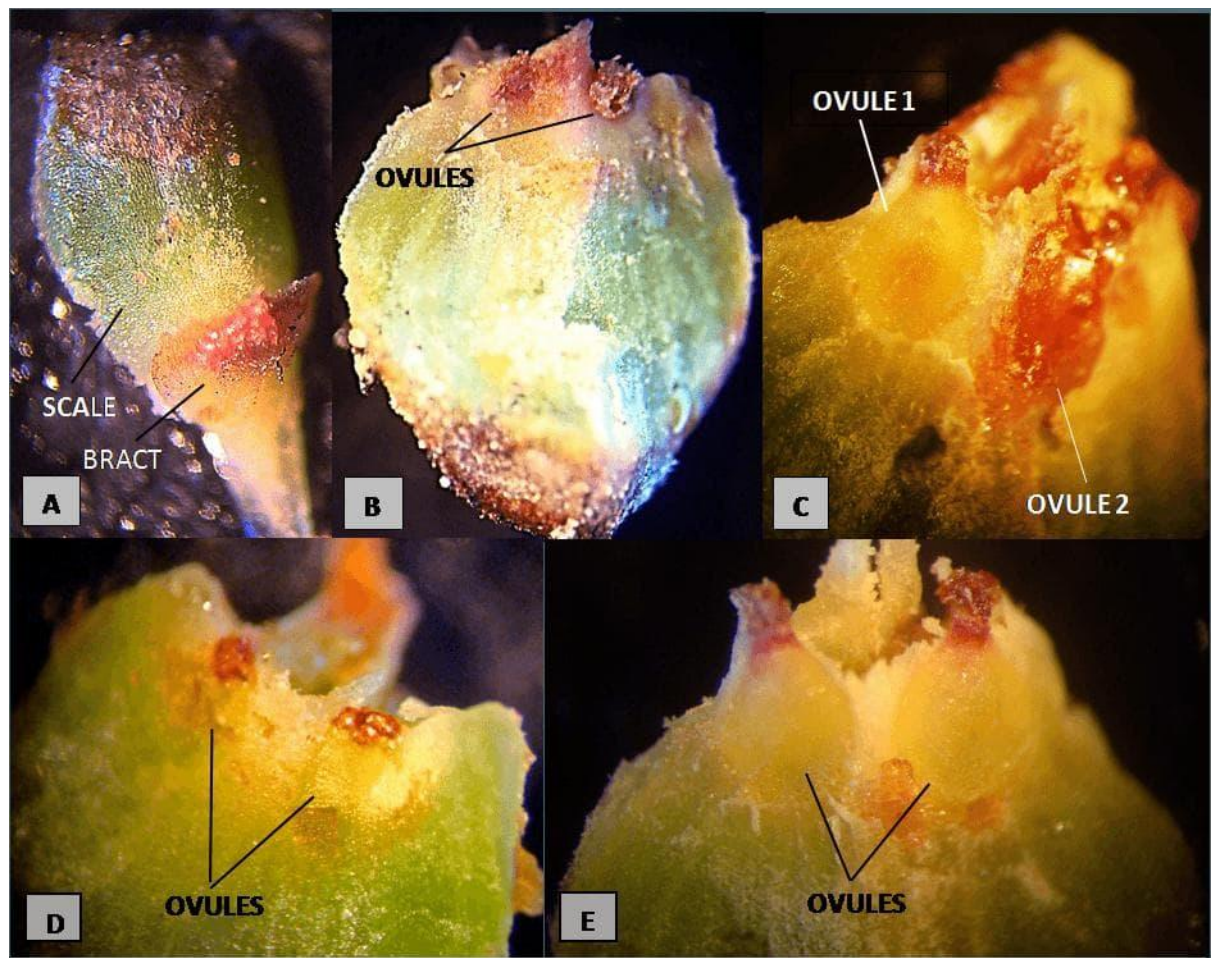

Figue 1. Scales in female cone of Pinus pumila: A - complex of not fused bract and ovuliferous scale (scale), B - two nonpollinated ovules, $\mathrm{C}$ - two pollinated ovules: 1-normally develops, 2 - degenerates, D - two pollinated ovules that stopped their development soon after pollination,

E - two successfully developed ovule

Cones of both species included fertile and sterile scales located only at the bottom of cones (we don't mind 2-3 fused scales which formed the tip of cones). It has been previously reported that the proportion of sterile and fertile regions of the cones varies among clones of the same species and varies considerably among species of pine (Owens, 2006). Thus in Pinus albicaulis Engl. sterile scales present at the top and at the bottom of cones (Owens et al., 2008). In the studied species sterile scales are of two types - scales without ovules which are mostly located at the base of the cone (5-8 per cone in P. pumila (Kyiv) and 8-10 (Gorgany) and 5-6-P. armandii) and scales with rudimentary ovules (Fig. 2 A) that formed the region between sterile and fertile scales in the cones of both species (3-9 per cone of $P$. pumila and 6-8 $-P$. armandii). Those rudimentary ovules had small micropylar arms, rudimentary nucellus, and the megaspore development did not occur.Besides, in the upper part of some P. pumila cones (just near the tip) complexes of not fused bracts and ovuliferous scales (scale) with rudimentary ovules were noticed (Fig. 1 A). 


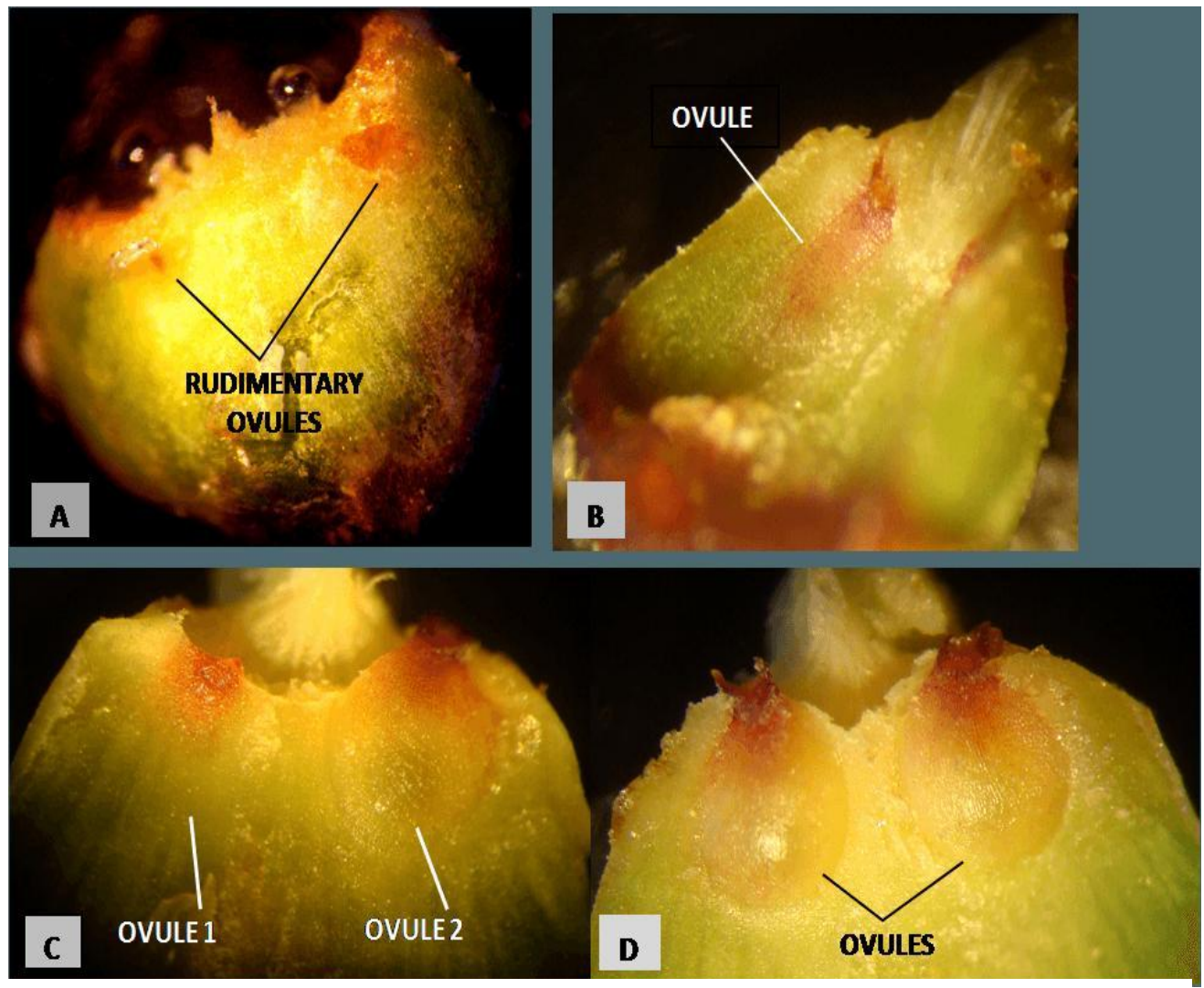

Figure 2. Scales in female cone of Pinus armandii: A - two rudimentary ovules,

$\mathrm{B}$ - nonpollinated ovule, $\mathrm{C}$ - two pollinated ovules differed in size: the smaller one degenerated (1) and the other ovule developed (2), D - two successfully developed ovules.

J.N. Owens et al. (2008) recognized eight categories of seeds in mature cones of Pinus albicaulis Engelm. The same categories we recognized in mature cones of Pinus sibirica (Pohilchenko, Ruguzova, 2014). And in this study we examined $P$. pumila and $P$. armandii cones at the time of their winter dormancy. At this developmental stage ovule categories similar to those in mature cones could be noticed. The first type are fertile scales with two small flat ovules that hadn't been pollinated and had no further development (23-28\% of total fertile scales per cone in P. pumila and 21-26\% in P. armandii) (Fig. 1 B, 2 B)

The second type is scales with two pollinated ovules that stopped their development soon after pollination (7-19\% in P. pumila) (Fig. 1 D). The third type is scales with two pollinated ovules differed in size - the smaller one degenerated and the other ovule developed (19-31\% in P. pumila and $13-45 \%$ in $P$. armandii) (Fig. $1 \mathrm{C}, 2 \mathrm{C}$ ). And the last type is scales with two successfully developed ovules $(22-40 \%$ in $P$. pumila and $34-60 \%$ in P. armandii) (Fig. 1 D, 2 
D). It did not notice any significant differences in scale number and proportion in P. pumila cones from Kyiv and Gorgany.

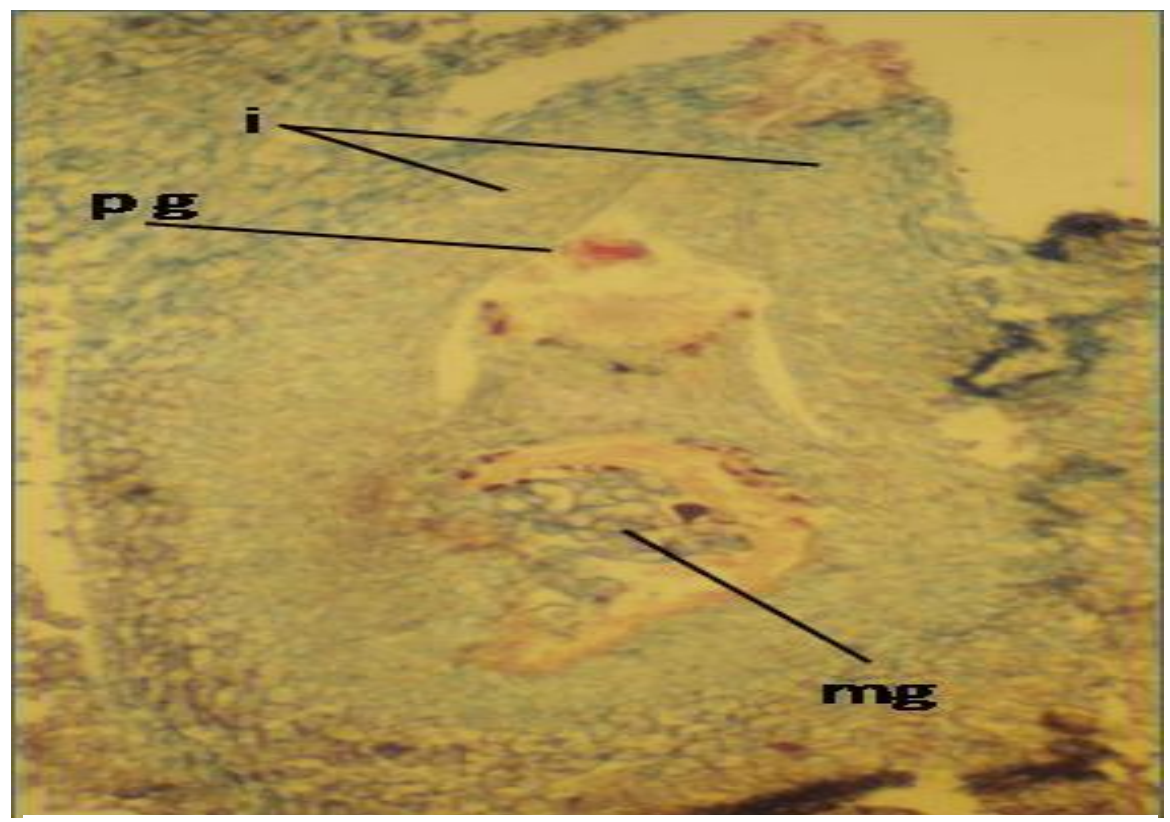

Figure 3. Pinus pumila normally developed ovule ( $\mathrm{i}$ - integument, $\mathrm{mg}$ - megagametophyte, $\mathrm{pg}$ - pollen grains)

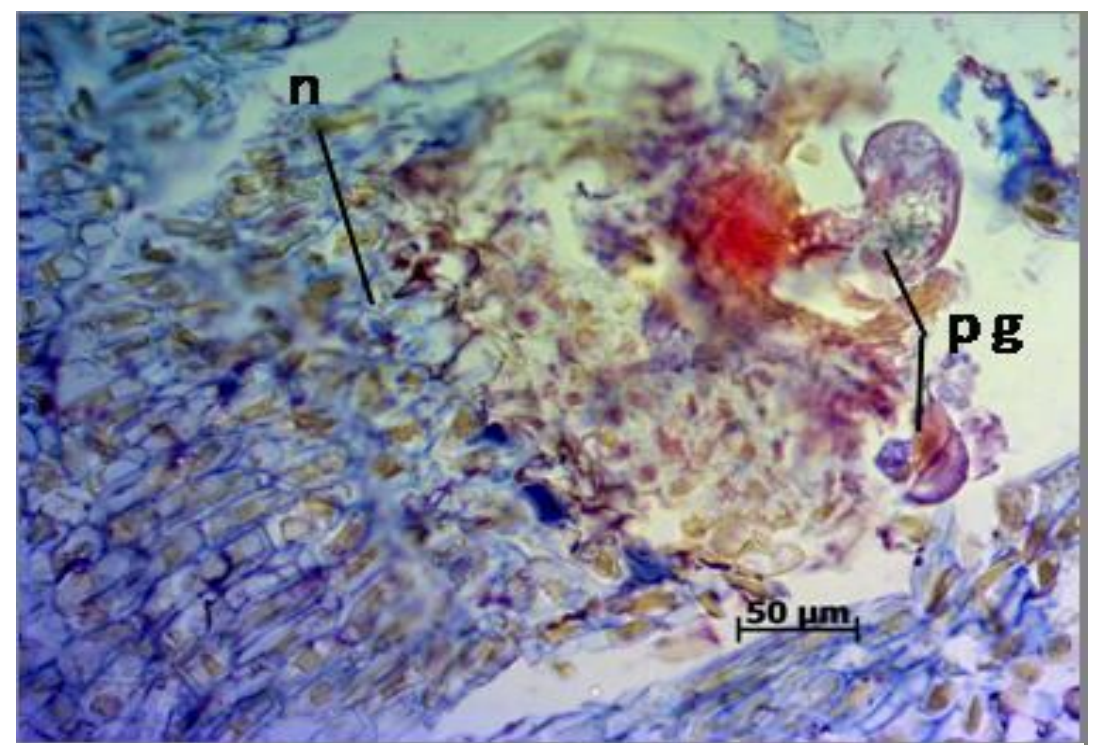

Figure 4. Pinus armandii degenerated ovule with growing pollen grains ( $\mathrm{n}$ - nucellus, $\mathrm{p} \mathrm{g}$ - pollen grains) 
Under the light microscope developing pollen grains with tubes were noticed in all pollinated ovules they either developed or degenerated (fig 3,4). Those observations demonstrated that there are some reasons of ovule degeneration besides the lack of pollination.

Our observations correspond to those made for Pinus lambertiana Dougl. seed cones pollinated with Pinus monticola Dougl. ex D.Don pollen grains (Fernando et al., 2005). The cross between two species resulted in the failure of megagametophytes at the free-nuclear stage that could relate to the presence of the incompatible pollen tube on the nucellus. Since our studied pine trees are the part of dendrological collection and they are neighboring to the other Pinus species cross pollination could possibly be one of the reasons for ovules degeneration during the second year of their development. However, the mechanism of this incompatibility reaction is unknown and it needs further studies. The other possible reason of megagametophyte degeneration at the stage of free nuclear is rusts diseases caused by pathogenic fungi. M.B. Rayachhetry et al. (1995) studied histology of Pinus maximinoi cones infected by one of the cone-rust fungus species and observed some ovules contained spongy tissue with degenerating cells in the centre.

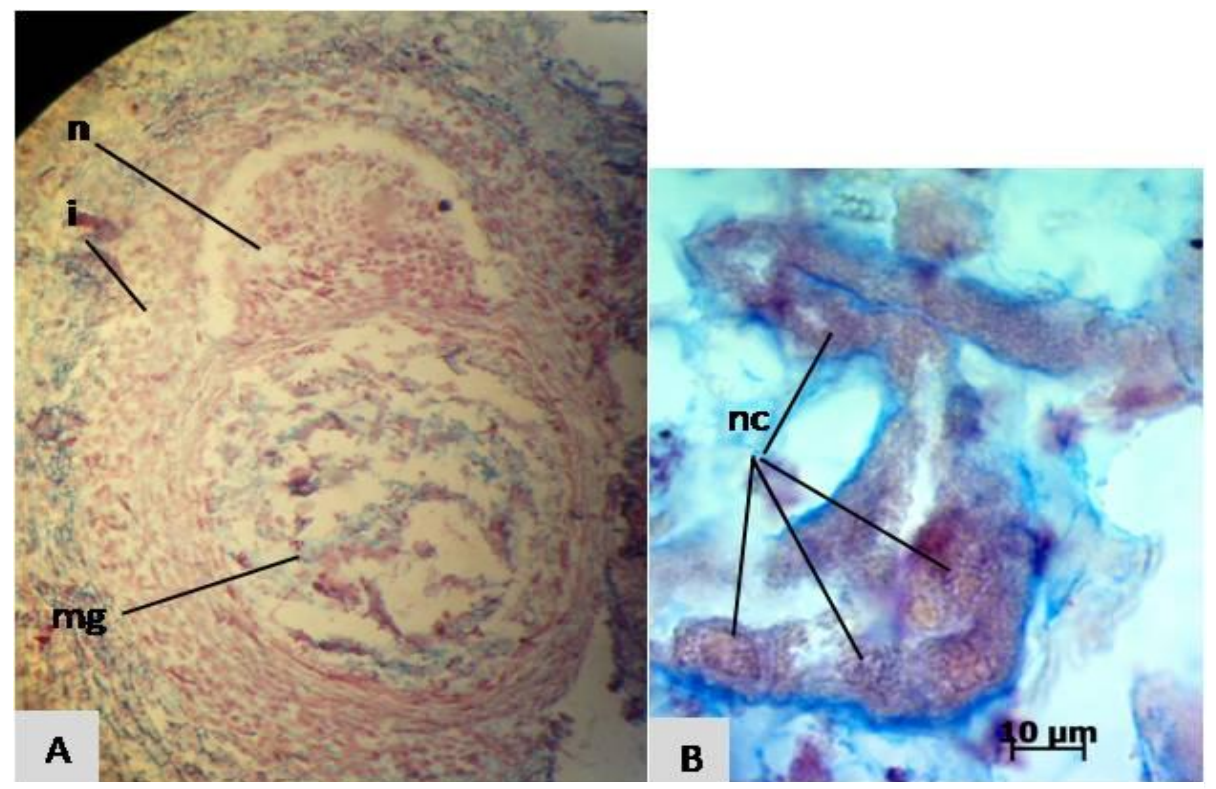

Figure 5. A - Developed ovule in Pinus armandii. Megagametophyte at the free nuclear stage.

$\mathrm{B}$ - megagametophyte nuclei

For both species in the most of normally developed ovules megagametaphyte was at the stage of free nuclear (fig. 5 A) but in some P. armandii ovules we observed the initiation of alveolar stage. At these stages 
ovules had well developed integument the micropillar parts of which have been closed up soon after pollination.

The upper part of nucellus is elongated and on its tip pollen chamber has been formed. Free nuclear megagametophyte located in the basal part of the ovule and attached with tapetum (spongy tissue).

At that time its cell walls have dissolved and tapetum was of plasmodial type. It had dense cytoplasm and large nuclei. In P. armandii mean $( \pm S E)$ diameter of spongy tissue nuclei was $19.09 \pm 1.30 \mu \mathrm{m}$ and for free nuclei it was $12.59 \pm 1.33 \mu \mathrm{m}$ (fig. $5 \mathrm{~B}$ ).

\section{CONCLUSION}

Our data about $P$. pumila and $P$. armandii female cones development correspond with other reports about Pinus sp. of different systematic groups (Zhang et al. 2015, Surso, 2015, Lill, 1974). That let us to suppose that these species are well adapted to the new growth conditions. For both studied species the main reason of poor seed formation was lack of pollination. Also, abortion of the pollinated ovules during the second year of their development was observed and its reasons need detailed studies.

\section{REFERENCES}

Fernando D.D., Long S.M., Sniezko R.A. 2005. Sexual reproduction and crossing barriers in white pines: the case between Pinus lambertiana (sugar pine) and P.monticola (western white pine). Tree Genetics \& Genomes 1: 143-150.

Flora of China, Volume 4. http://www.efloras.org/florataxon.aspx?flora _id=2\&taxon_id=200005356 (accessed February 20, 2016).

Goroshkevich S.N., Popov A.G., Vasilieva G.V. 2008. Ecological and morphological studies in the hybrid zone between Pinus sibirica and Pinus pumila. Ann. For. Res. 51: 43-52.

Lill B.S. 1974. Development of the female cone of Pinus radiate D. Don. Vol.1 A thesis presented for the degree of Doctor of philosophy in Botany in the University of Canterbury, Chriatchurch, New Zealand.

http://ir.canterbury.ac.nz/bitstream/handle/10092/6079/lill_thesis_vol1.pdf;jsessionid=AE 8D2C4E173A507DA52698C20A7A5ADF?sequence=1 (accessed February 18, 20160.

Owens J.N. The Reproductive Biology of Lodgepole Pine FGC extension note prepared for the Forest Genetics Council of British Columbia, 1936. - Published, 2006. 62 p. http://www.fgcouncil.bc.ca/ExtNote7-Final-web.pdf (accessed February 24, 2016).

Owens J.N., Kittirat T., Mahalovich M.F. 2008. Whitebark pine (Pinus albicaulis Engelm.) seed production in natural stands. Forest Ecology and Management. 255 (3-4): 803-809.

Pausheva Z.P. 1990. Practical Handbook on Plants Cytology. Moscow. [Russian] [Praktikum po tsitologii rastenii].

Ruguzova A.I., PokhYlchenko O.P. 2014. Embryological features of Pinus sibirica Du Tour seeds formation in Kiev. Plant Introduction. 2 (62): 10-17. [Russian] [Embryologicheskie aspekti formirovania semyan Pinus sibirica Du Tour v usloviyah Kieva] 
Rayachhetry M.B., Webb R.S., Miller T., Kimbrough J.W. 1995. Histology of Pinus maximinoi cones infected by Cronartium conigenum. Eur. Jour. For Path. 25: 100-108.

Shevchenko S.V., Ruguzov I.A., Efremova L.M. 1986. Methods for section staining by methyl-green and pyronin. Bulletin of the State Nikitsky Botanical Gardens, 60: 99-101. [Russian] [Metodika okraski postoiannyh preparatov metilovym zelenym I pironinom].

Sklonnaya L.U., Ruguzov I.A., Kostina V.P. 1992. Methodical recommendations for efficient use of Juniperus foetidissima Willd. crimean germplasm. Yalta. Nikita Botanical Gardens. [Russian] [Metodicheskie recomendatsii po ratsionalnimu ispolzovaniyu krimskogo genofonda Juniperus foetidissima Willd.]

Surso M.V. 2015. Microphenology of the Female Reproductive Cycle and Structure of Seed Crops of Scotch Pine in the Northern Taiga. Lesnoj dzhurnal, 2: 50-62. [Russian] [Microfenologiya zhenskogo reproduktivnogo cykla I struktura urozhaev semyan sosni obiknovennoy v severnoy taige].

Vasilyeva G.V., Goroshkevich S.N. 2013. Crossability of Pinus sibirica and P. pumila with their hybrids. Silvae Genetica, 62 (1-2): 61-67.

Wang H., Hong J. 2004. Genetic Resources, Tree Improvement and Gene Conservation of Five-Needle Pines in East Asia. USDA Forest Service Proceedings RMRS-P32.: 73-78.

Wang X., Zhao Y., Sun W. 2007. Blooming characeristics in clonal seed orchard of Pinus armandii. Jilin Forestry Science and Technology. http://en.cnki.com.cn/ Article_en/CJFDTotal-JLLK200705002.htm [Abstract]

Zhang, R.; Hu, X.; Wu, X.; Wang, Y. 1992. Study of reproductive biology of clonal seed orchard of Pinus armandii. In: Shen Xihuan, ed. Seed Orchard Techniques. Beijing Science \& Technology Publishing House: 185-191.

Zhang W., Zheng C.-X., Zhao N., Li F. 2015. Observation on the formation of ovule tapetum in Pinus tabulaeformis Carr. Journal of Beijing Forestry University, 37 (7):

https://www.researchgate.net/publication/283439044_Observation_on_the formation_of_ovule_tapetum_in_Pinus_tabulaeformis_Carr (accessed January 22, 2016). 